\title{
Rudolf Bultmann - Evangelie en geloof
}

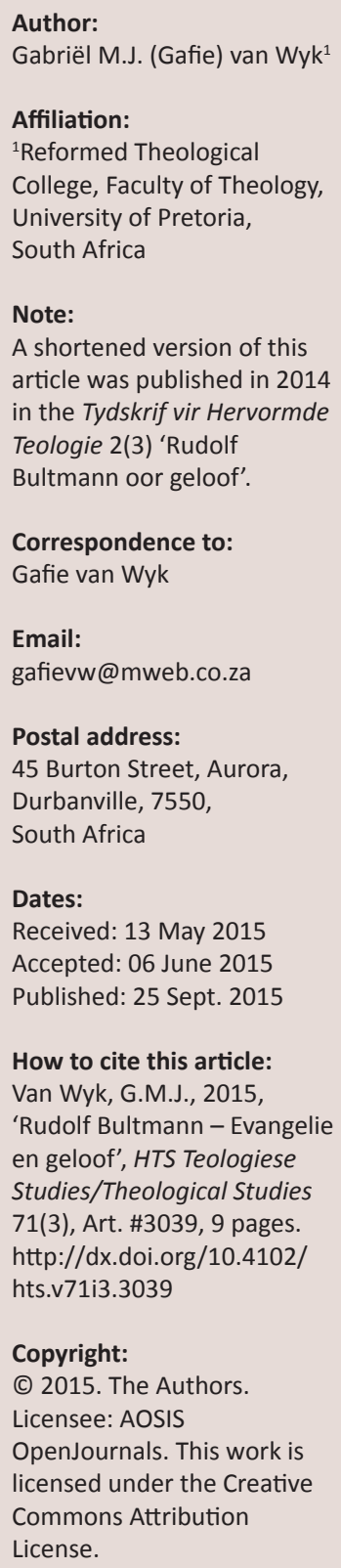

Rudolf Bultmann - The Gospel and faith. Although the name Rudolf Bultmann is well known in South African ecclesiastical circles, many South Africans distrust his theology because of prejudice and the suspicion that it is not faithful to scripture. A synopsis of Bultmann's own theological description of faith is presented here with the focus on its historical development and with the aim in mind to serve as an apology for a better understanding of his point of view within the context of his life as a confessing Lutheran. The essay ends with a concise critical evaluation of Bultmann's understanding of Christian faith pointing out its continual value for the current theological debate on the meaning of faith, as well as some minor conditional reservations on his arguments.

\section{Inleiding}

Kan nog 'n artikel, naas baie ander, wat fokus op Bultmann se beskrywing van geloof geregverdig word? Is dit nodig om so 'n artikel in 2015 in Afrikaans aan te bied? Ek is oortuig die antwoord op beide vrae is 'ja'. Hoewel daar periodiek uitstekende werk oor Bultmann se geloofsverstaan gepubliseer is wat sy denke oor geloof sistematies in samehang met sy uitgebreide eksegetiese en sistematies teologiese nalatingskap bespreek, dit in terme van die teologiegeskiedenis, algemene kultuurgeskiedenis en filosofie kontekstualiseer en krities analiseer, bestaan daar binne die Afrikaanssprekende gemeenskap steeds vooroordeel en agterdog oor Bultmann wat op wanvoorstellings van sy teologie gebaseer word. Twee uiteenlopende resente artikels oor Bultmann se geloofsverstaan deur Von Sass (2011) en die Bultmann-biograaf Hammann (2012a) toon egter aan dat hoewel daar sekere onduidelikhede in Bultmann se werk aangedui kan word (wat veral verband hou met die keuse van terminologie), sy teologie met geringe voorbehoude steeds met vrug ingespan kan word om die evangelie in ons hedendaagse leefwêreld te verduidelik en oortuigend te verkondig sodat dit geglo kan word. Om saaklike teologiese redes (wat weldra aangedui sal word) is die geval Bultmann nog lank nie 'n afgehandelde saak nie. Met die histories georiënteerde oorsig wat aangebied word, word tegelyk na die ontwikkeling en essensie van Bultmann se verstaan van geloof gevra.

\section{Bultmann se geloofsverstaan}

Rudolf Bultmann het 'n ortodokse Christelike opvoeding ontvang (Hammann [2009] 2012b:10). Sy vader, Arthur Kennedy Bultmann, was predikant en tot ongeveer 1900 sou sy teologiese benadering as piëtisties en biblisties getipeer kon word, maar daarna het hy stelselmatig oorbeweeg tot die vrye Protestantisme en sou sy teologiese benadering as liberaal beskryf kon word. Bultmann se moeder, Helene, was predikantsdogter en het lewenslang getrou gebly aan die herlewingsdenke waarin sy opgevoed is (Hammann [2009] 2012b:2-3). Sedert sy laaste gimnasiumjare het Rudolf Bultmann begin om krities te besin oor die ortodokse opvattings aangaande geloof waarin hy opgevoed is en wat hy aanvanklik met oortuiging verdedig het. Bultmann berig dat dié transformasieproses moeisaam was, maar terugskouend vertel hy in 1914 dat dit vir hom verlossend was om hom te bevry van valse navorsingsmetodes, bedrieglike voorstellings van die hiernamaals en die betowering van die verouderde kerklikheid (Hammann [2009] 2012b:10-11).

Bultmann skryf reeds in 1906 as student in 'n studieopdrag oor 1 Korintiërs 2:6-16:

[Der Glaube ist] kein Fürwahrhalten von Objekten, die sich von den Objekten des erkennenden Geistes gar nicht prinzipiell unterscheiden, sondern er ist persönliche Überzeugung, entsprungen aus dem Erlebnis der Berührung mit einer unbedingten Macht. (aangehaal uit Hammann [2009] 2012b:35)

In 'n preek wat Bultmann teen die einde van 1911 in Marburg oor 1 Korintiërs 7:29-31 gelewer het, verstaan hy godsdiens nog binne die raamwerk van sedelike funksionaliteit en laat hy die evangelie aan die woord kom teen die agtergrond van die wet, maar stel hy tog in die ontknoping van die argument wat gevoer word, dat geloof as geskenk onverdiend aan mense die toekoms 
open, deurdat mense hulle eie sedelik goeie werke te bowe kom deur die hoor van die evangelie om die toekoms as daad en werk van God te verstaan (Hammann [2009] 2012b:68; Hauschildt 1989:20-59). Gedurende 1913 stel Bultmann (1913:123-127; 133-135) in die referaat 'Theologische Wissenschafte und kirchliche Praxis' dat histories bemiddelde kennis nie die grondslag van geloof kan wees nie. Die wese van evangeliese geloof, meen hy, is nie in kennis gegrond nie, maar wel in die gewete wat die stem van God hoor. Hiermee bring Bultmann ' $n$ tema (ontleen aan Luther se teologie) op die voorgrond wat ' $n$ lang nawerking in die geskiedenis van die teologie sou hê (Ebeling [1967] 1969a:138-183; 1979:132133; Pannenberg 1993:184-196).

In 'n resensie wat in 1922 geskryf is oor die tweede uitgawe van Karl Barth se Römerbrief benadruk Bultmann dat geloof nie menslike besit is nie, maar beskryf hy ook Barth se opvatting dat mens net kan glo dat jy glo as 'Glauben jenseits des Bewusstseins' en daarom as 'n absurditeit. Teenoor Barth meen Bultmann dat geloof deurlopend die inhoud van ons bewussyn op 'n eiesoortige wyse bepaal (Bultmann [1922] 1977b:129-130). Reeds in 1924 handhaaf Bultmann ([1924] 1980b:1-25) egter nie meer hierdie standpunt nie. Hy stel dat geloof nie ' $n$ toestand van die bewussyn is nie. God skep geloof in mense, daarom kom geloof nie deur enige menslike aktiwiteit tot stand nie en kan dit ook nie in die gewone lewe aangedui word nie. Die gelowige is nie die natuurlike mens nie, maar die mens wat saam met Christus gesterwe en opgestaan het. Bultmann kan nou die paradoksale formulering van Barth (en Luther) onderskrywe dat gelowiges net kan glo dat hulle glo.

Vroeg in 1925 gee Bultmann ([1925] 2002b:249-277) in 'n voordrag aandag aan die verhouding tussen teologie en historiese eksegese. Hy verdedig die standpunt dat dit nie moontlik is om vanuit 'n neutrale standpunt vas te stel wat 'n teks beteken nie. Mens moet die aansprake van die teks ter harte neem. Dit beteken dat die eksegeet bemoeienis moet maak met die saak waaroor die teks handel en dat die uitleg aangepak moet word met die waarheidsvraag in die oog. Nuwe Testamentiese eksegese behoort metodologies die algemene standaard van wetenskaplike teksuitleg te volg, maar dit word eers 'n sinvolle onderneming wanneer dit as teologiese eksegese geloof veronderstel. Trouens, teologie as sodanig, moet ook geloof veronderstel. In dieselfde jaar verdedig Bultmann (1925:172) in 'n ander voordrag die standpunt dat geloof nie 'n wêreldbeskouing, algemene vertroue op God, of mistieke kontak tussen die siel en God is nie, maar wel die menslike benadering om binne 'n konkrete situasie jou deur God te laat aanspreek.

Gedurende 1926 verdedig Bultmann ([1926] 2002a:156-157) in 'n koerantartikel die standpunt dat in die teologie geloof nie net fenomenologies in terme van die psige van die mens of die kultuur- of godsdiensgeskiedenis moet beskryf word nie, maar dat die intensionaliteit van geloof altyd ook ter sprake moet kom wanneer daaroor besin word. Omdat teologie oor geloof handel, moet dit noodwendig ook oor God handel en omgekeerd.
Hoewel Bultmann in sy boek Jesus, waaraan hy waarskynlik sedert die wintersemester van 1924-1925 geskryf het, maar wat eers in 1926 gepubliseer is, slegs 'n kort stukkie van ongeveer een bladsy aan die geloofsbegrip wy, het hy tog in die bespreking van dié werk insiggewende opmerkings teenoor sy kritici gemaak oor sy verstaan van geloof. Bultmann ([1926] 1977a:130) wys in sy Jesus-boek daarop dat Jesus nie 'n intellektualistiese geloofsbegrip gehandhaaf het in die sin van ' $n$ algemene teoretiese oortuiging of wêreldbeskouing wat ruimte laat vir die bestaan van God nie. Geloof is vir hom die krag om in konkrete situasies erns te maak met die oortuiging van God se almag en om ook werklik sy handeling te ervaar met die gevolg dat die ver en verborge God in der waarheid naby kom. In hierdie sin is geloof gehoorsaamheid aan God.

In gesprek met Emanuel Hirsch gee Bultmann ([1927] 1980c:85-113) in 'n artikel, Zur Frage der Christologie, in 1927 weereens aandag aan die geloofsbegrip. Hy oordeel dat Hirsch se benadering om geloof te wil herlei tot die innerlike ervaring van die gelowige met Jesus net so illegitiem is as Wilhelm Herrmann se benadering om geloof te wil begrond in die innerlike lewe van Jesus. Bultmann oordeel met verwysing na Romeine 10:17 dat geloof deur die gesagvolle verkondiging van die evangelie ontstaan. Die Woord het nie enige legitimasie naas die evangelieboodskap self nodig nie, want die Woord vorm self die basis vir geloof.

Sedert die wintersemester van 1925-1926 doen Bultmann intensiewe navorsing oor die Pauliniese teologie wat in 1930 teregkom in 'n artikel Paulus, wat in die tweede uitgawe van Die Religion in Geschichte und Gegenwart (Bultmann [1930] 1927-1931:1019-1045) gepubliseer word. Bultmann het ongeveer twee dekades later die inhoud van hierdie artikel, met geringe wysigings, deel laat word van sy Theologie des Neuen Testaments (Bultmann [1948-1953] 1961:187-353). Die invloed daarvan kan ook bespeur word in die artikel ' $\pi$ í $\tau \imath \varsigma^{\prime}$ ' wat in die Theologisches Wörterbuch zum Neuen Testament van 1968 (Bultmann 1968b:174-228) verskyn het. Die sentrale plek wat Bultmann aan die tema geloof toeken in sy interpretasie van Paulus se teologie dui reeds daarop dat geloof 'n belangrike fokuspunt van Bultmann se eie teologie geword het. Bultmann beskryf Paulus se teologie as antropologie omdat Paulus die mens coram Deo aan die orde stel. Hy vind die essensie van Paulus se teologie daarin dat Paulus die voorgelowige bestaan van mense onderskei van 'n lewe in geloof. Mense se voorgelowige lewe kom tot uitdrukking as sonde omdat mense hulle buite die geloof self wil laat geld. Gelowige mense ontdek egter die waarheid van hulle lewens (Eigentlichkeit) deur die geskenkte geregtigheid van God, wat in die dood en opstanding van Christus as heilsdaad voltrek word en die gelowige, wat die verkondiging van die evangelie as eskatologiese heilsgebeure aanhoor, tot 'n nuwe selfverstaan bring, sodat hulle voortaan hulle lewens deur die Gees laat bepaal. Waar voorgelowige mense onder die heerskappy van die wet, sonde en dood staan, lewe die gelowiges in vryheid om deur diens aan die naaste die gebod van die liefde te vervul. 
Met die verskyning van die tweede uitgawe van Die Geschichte der synoptischen Tradition in 1931 word nie alleen lig gewerp op Bultmann se begrip van wat geloof is nie, maar word dit ook verder duidelik watter sentrale plek die begrip voortaan in sy eie teologie sou inneem. Bultmann se leermeester Wilhelm Herrmann het reeds daarop gewys dat geloof nie deur sogenaamde historiese feite gelegitimeer kan word nie. In aansluiting hierby wys Bultmann daarop dat die Evangelies nie aan ons berigte aanbied oor die lewe en werk van die historiese Jesus nie. Die fokuspunt van die Evangelies is die verkondiging van Jesus as die gekruisigde en opgestane Here en die mensgeworde Seun van God. Om die evangeliese boodskap aan te dui, gebruik Bultmann by voorkeur die begrip kerugma, wat deur Martin Debelius geyk is. Die inhoud van die Christelike kerugma is nie die historiese Jesus nie, maar die Christus van die geloof en die Christelik godsdienstige kultus. Die kerugma verkondig dat die Seun van God op aarde geleef, gely, gesterwe en opgestaan het, en toe ook tot die hemelse heerlikheid verhoog is (Bultmann [1931] 1979:396).

Die veelbesproke kontak tussen die filosoof Martin Heidegger en Bultmann het veral beslag gekry min of meer in dieselfde tyd as waarin Heidegger se werke Sein und Zeit ([1927] 2001) en Phänomenologie und Theologie ([1927] 1978) verskyn het. Uit die gesprek met Heidegger blyk dit duidelik watter belangrike rol geloof in die denke van Bultmann speel. Bultmann beskryf die vervallenheid van mense wat hulle van outentieke bestaan ontneem in die lig van die openbaring as sonde. Deur die koms van Jesus, die Openbaarder, word twee wedersyds uitsluitende bestaansmoontlikhede (Daseinsmöglichkeiten) vir mense ontsluit, naamlik lewe in geloof of lewe in ongeloof. Die verkondiging van die Evangelie skep oombliklik 'n eskatologiese krisis, in die sin dat mense daar en dan tussen 'n lewe in geloof of een in ongeloof moet kies. Bultmann meen dat, vanuit die oogpunt van die geloof, kan die keuse van 'n filosofiese lewensbenadering alleen as ' $n$ daad van selfgenoegsame vryheid beoordeel word, waarin die mens se afhanklikheid van God verloën word (Bultmann 1984:89).

Tussen 1926 en 1936 bied Bultmann vyf voorlesingsreekse aan oor die inleiding tot teologiese studie wat later gepubliseer sou word onder die titel Theologische Enzyklopädie (Hammann [2009] 2012b:207). In hierdie werk, waarvan verskeie gedagtes in gesprek met Heidegger ontwikkel is (Jüngel 1990:31-36), kom die fundamentele verskille tussen Bultmann en Schleiermacher aan die lig. Soos Schleiermacher verklaar Bultmann teologie tot 'n positiewe wetenskap, maar die onderwerp wat teologie bestudeer, meen hy, is nie die Christendom as historiese fenomeen nie, maar wel die geloof wat die Christendom tot Christendom maak en wat sowel die Christendom as die teologie konstitueer (Bultmann 1984:12). Bultmann maak daarom die regte leer (reine Lehre) die vertrekpunt vir die vraag na die onderwerp van teologiese studie (Bultmann 1984:15). Die vraagstelling van teologie is wat die regte leer is wat die kerk deur haar prediking moet verkondig. Bultmann bedien homself in hierdie verband van 'n onderskeid wat deur Augustinus getref is (Von Sass 2011:253) en wat' $n$ fundamentele grondslag van al sy verdere denke oor geloof sou bly. Die somtotaal van die kerklike verkondiging deur die prediking kan formeel beskryf word as geloof in die sin van fides quae creditur [geloofsinhoud]. Teologie is nie geloofsleer in die sin van leer oor fides qua creditur [geloofsdaad] nie. Waar geloof in laasgenoemde sin verstaan word, het die teologie reeds haar eintlike onderwerp van studie prysgegee. Daarom kan Bultmann redeneer dat daar alleen oor geloof gepraat kan word wanneer tegelyk oor God gepraat word (Bultmann 1984:21).

Bultmann verdedig sy geloofsopvatting op twee fronte. Aan die een kant grens hy hom van die liberale teologie van die negentiende eeu af deur aan te voer dat dié teologie, wat die geloofsdaad deur middel van die godsdienswetenskaplike godsdiensbegrip interpreteer, geloof slegs as fides qua creditur aan die orde stel. Die resultaat is dat die fides quae creditur uit die gesigsveld verdwyn, met die gevolg dat die waarheidsvraag ook prysgegee word. Geloof word gevolglik as menslike houding verstaan en dit word oor die hoof gesien dat geloof alleen binne ' $n$ spesifieke gerigtheid van mense op 'n bepaalde onderwerp beslag kry (Bultmann 1984:31). Bultmann meen dat die protestantse ortodoksie, anders as die liberale teologie, wel geïnteresseerd was in die waarheid van die fides quae creditur en die intensionele gerigtheid van geloof op haar onderwerp, naamlik die heilswerk van God. Die wyse waarop die ortodoksie die geloof in drie opeenvolgende momente onderskei as notitia (Erkenntnis), assensus (Zustimmung) en fiducia (Vertrauen) ondergrawe egter die vermeende benadering wat aanvanklik gevolg is. Ortodoks gesien, veronderstel ware geloof, dat sekere heilsfeite onderskrywe moet word, met die gevolg dat geloof te make het met die blote instemming ten opsigte van die regte leer. Die kerugma word met 'n wetenskaplike teorie vervang en die Woord van God word prysgegee ter wille van menslike leerstellings oor die Woord (Bultmann 1984:31). Om die probleme waarin sowel die ortodokse as liberale teologie vasgeloop het te bowe te kom, moet die fides quae creditur en die fides qua creditur in wisselwerking met mekaar oordink word. God kan alleen verstaan word, wanneer verstaan word wat geloof is en omgekeerd kan geloof alleen verstaan word, wanneer verstaan word wie God is (Bultmann 1984:34).

Bultmann ontwikkel sy opvatting oor geloof in samehang met sy begrip van openbaring en in kritiese gesprek met die kerklike tradisie. Volgens Bultmann (1984:69-71) verstaan die Middeleeuse skolastiek en die protestantse ortodoksie geloof as 'n soort kennis en openbaring as die bekendmaking van hierdie kennis. Hierteenoor stel Bultmann (1984:88) dat die Bybel openbaring as historiese gebeure beskryf, naamlik as die Woord van God wat die mens hoor en die waarheid van die oomblik sigbaar maak en so tegelyk God sigbaar maak. Die openbaring word voltrek deurdat God die mens deur sy Woord aanspreek en so sy geskiedenis onderbreek deur die vergifnis van sonde aan hom te bied. Deur die Woord van vergewende liefde roep God mense om van hulle verlede af te sien, wat deur hulle eie werke bepaal is, en hulle lewe nou deur die toekoms van God as nuwe moontlikheid te laat bepaal. Die historiese gebeure wat Jesus Christus as Woord van God daarstel, skep die moontlikheid dat mense 
hulleself in die geloof nuut kan verstaan. Geloof is primêr die gehoorsame aanname van die kerugma van Jesus Christus en nie die onkritiese aanvaarding van 'n historiese mededeling nie. Geloof is self die sekerheid dat die geskiedenis van Jesus Christus die geskiedenis van heil is. Die gelowiges verlaat hulle geheel en al op die woord van sondevergewing wat aan hulle toegespreek word (Bultmann 1984:130).

Bultmann benadruk die geskenkkarakter van geloof (Bultmann 1984:120). Deur geloof ontvang mense sondevergewing en nuwe lewe in Christus. God skenk aan mense geregtigheid. As gelowige ontvangers van goddelike genade is mense passief. Bultmann meen egter ook dat geloof as daad in die geskiedenis voltrek word. Die daadkarakter van geloof dui aan dat die passiwiteit van gelowiges nie verkeerd verstaan moet word nie. Om Bultmann se oënskynlike paradoksale standpunt te kan begryp, moet daarop gelet word dat hy onderskeid tref tussen daad en werk. Werk dui op die resultaat van handeling, wat gevolglik voorhande is. Daad dui weer op die handeling as sodanig en nie op die resultaat daarvan wat voorhande is nie (Bultmann 1984:134). Wanneer mense hulle lewens vanuit die perspektief van hulle werke beoordeel, verstaan hulle hulleself vanuit die voorhande werklikheid en so ontglip die moontlikheid tot werklike vryheid hulle. Die verkondiging van die Evangelie bevry mense vanuit hierdie selfopgelegde onvryheid deurdat hulle opnuut van die moontlikheid hoor, om ontvanklik vir God se toekoms, binne die waarheid van die oomblik hulleself nuut te ontdek as bevryde mense. Aan die een kant ontvang die gelowige mense passief die heil wat God se Woord aan hulle toesê, maar aan die anderkant ontvang die mens die heil alleen deur 'n daad van vrye keuse. Gelowige mense is mense wat die besluit neem om hulle lewens nie langer te laat bepaal deur hulle eie verlede nie, maar wel deur gehoorsaamheid aan die kerugma wat hulle van God se liefde verseker en hulle bevry om ander lief te hê.

Hoewel Bultmann se Johanneskommentaar eers teen 1941 volledig gepubliseer word, was die grondkontoere vir die eksegese reeds teen 1930 volledig uitgewerk (Bultmann 1978; Hammann [2009] 2012b:297). Die kommentaar bied aan ons 'n perspektief van Bultmann se geloofsverstaan aan die hand van Johannes vir dié tydperk. Bultmann verstaan die teologie van die Johannesevangelie hoofsaaklik as die uitleg van die sin 'Die Woord het vlees geword' (Johannes 1:14). Met die vleeswording van die Seun van God word die eskatologiese heil as historiese gebeurtenisse in die teenwoordigheid van die mense gebring. Jesus openbaar die werk van God asook God se heerlikheid omvattend. Hy voltrek God se werk en praat sy woorde. In Jesus se nederige menslike lewe word God self ontmoet. Jesus plaas elke mens voor die eskatologiese krisis, die onontwykbare keuse, om deur geloof en die openbaring van die Seun heil van God te ontvang, of om in ongeloof die Woord van die openbaarder af te wys en so dood en onheil te omarm. Die evangelie berig nie historiese feite oor die verlede nie, maar is self eskatologiese gebeure omdat die kerugma wat berig word opnuut die heilsaanbod van God teenwoordig maak sodat die mens wat die verkondiging hoor, voor 'n egte oomblik van waarheid, of oomblik van beslissing geplaas word om 'n antwoord op die goddelike liefde te gee wat geopenbaar word. Geloof beteken om die vryheid terug te ontvang wat die verlorenheid in sonde jou ontneem het en om in vryheid van die wêreld en jou eie verslawende verlede, self vry van sonde te lewe.

Teen 1941 verdedig Bultmann in sy voordragte ontmitologisering as hermeneutiese metode. In hierdie tyd is Bultmann nie alleen besorg oor die invloed van die wêreldbeskouing van die nasionaal-sosialistiese staat op die volksgodsdiens nie, maar ook oor die feit dat die belydende kerk (Bekennende Kirche) teologie tot die blote herhaling van die kerklike belydenisse beperk en die Christelike geloof net aanbied deur middel van argaïese taal en uitgediende wêreldbeelde. Die gevolg is dat die evangelie nie verstaanbaar of oortuigend verkondig word nie. Die evangelie moet in die taal van die hoorders verkondig word om geloofwaardig te wees. Dit is egter van belang om in te sien dat ontmitologisering nie bloot behels dat mitiese taal in wetenskaplike taal vertaal word, en dat 'n mitologiese wêreldbeeld met ' $n$ wetenskaplike een vervang word nie, want die Nuwe Testamentiese aanbieding van die heilsgebeure is self ook mitologies. Mitologiese motiewe uit die Joodse apokaliptiek en die gnostiese verlossingsmite is ook in die Nuwe Testamentiese verkondiging opgeneem (Bultmann [1941] 1998:13; Hammann [2009] 2012b:309).

Bultmann ontmitologiseer die Nuwe Testamentiese boodskap deur die onderskeiding van menslike lewe sonder geloof of lewe in geloof as uitgangspunt te neem. Sonder geloof leef mense van die sigbare en doenbare, wat verganklik is. Daardeur verval hulle in die dood en verloor hulle outentieke bestaan. Egte lewe, daarteenoor, ontvang mens in die vertroue dat die onsigbare en ondoenbare as liefde ervaar kan word, wat lewe en toekoms bied (Bultmann [1941] 1998:32-38). Hierdie liefde is niks anders as die sondevergewende genade van God nie. Deur geloof kry mens ook deel aan die eskatologiese bestaan wat God skenk. In geloof is die toekoms reeds teenwoordig en het die heilstyd reeds aangebreek. Die kruis en opstanding van Jesus is die sentrale kerugma van die Nuwe Testament (Bultmann [1941] 1998:52-54). Kruis en opstanding moet egter nie as objektiewe gebeure misverstaan word nie. Die kruis is as beslissende eskatologiese gebeure steeds vir die gelowige teenwoordig. Om aan die kruisiging van Jesus te glo, beteken om die kruis van Christus as jou eie aan te neem, en dit beteken om jou saam met Christus te laat kruisig (Bultmann [1941] 1998:55). Die opstanding is nie ' $n$ mirakel wat die betekenis van die kruis geloofwaardig maak nie, maar self ook objek van geloof. Geloof in Jesus se kruisiging as heilsgebeure is identies met geloof in sy opstanding. Ons ontmoet die gekruisigde en die opgestane Christus uitsluitlik in die verkondiging. Die verkondiging is daarom ook heilsgebeure.

Bultmann het konsekwent die standpunt gehuldig dat die teologie in diens van die kerklike prediking as die verkondiging van God se Woord staan (Hammann [2009] 2012b:321). Aan die een kant word die kerk deur die kerugma 
gekonstitueer en aan die anderkant bestaan die wesentlike opdrag van die kerk daarin om van die heil in Christus te getuig en dit verder in die wêreld te verkondig. Woord van God en kerk is onlosmaaklik aan mekaar verbonde. Die kerk word deur die Woord gekonstitueer en die woord is gesagvolle tradisie, daarom word die eskatologiese heilsgebeure deur die Woord in die kerk teenwoordig gemaak. Jesus Christus word alleen deur die prediking toeganklik (Bultmann [1929] 1980a, 153-154, 180). Net so word vergewing deur die Woord aan mense toegesê, wat hulle alleen in geloof kan aanneem. Vanuit hierdie perspektief kan Bultmann inderdaad beskryf word as 'n voortreflike verteenwoordiger van die Lutherse leer dat sondaars alleen uit geloof geregverdig word deur God.

Teen 1948 skryf Bultmann oor geloof vanuit die perspektief van die verhouding tussen Christendom en humanisme (Bultmann [1948] 1968a:133-148). Humaniste probeer om hulle lewens selfstandig te realiseer deur hulle eie werke. Gelowiges daarteenoor laat die waarheid opnuut aan hulle toesê deur die regverdigende Woord van God wat vergifnis van sondes bekendmaak. Hierdie Woord maak mense vry van 'n valse opvatting van die outonomie van die mens. Die gelowiges moet egter nie die evangeliese vryheid verpand deur toe te gee aan die opkomende klerikalisme wat 'n nuwe kerklike burokrasie wil vestig nie. Net so mag die evangelie nie verstar word tot ' $n$ Christelike leer in die vorm van die oorgelewerde belydenisse wat tot 'n ortodokse sisteem verhef word nie (Hammann [2009] 2012b:367).

In Das Urchristentum im Rahmen der antiken Religionen wat in 1949 verskyn gee Bultmann ([1949] 2000:206-210) weereens aandag aan geloof. Die oudste Christendom verstaan mense as in opstand teen God deur hulle eie wil te laat geld. Die mag van die bose oor mense kan nie verbreek word deur redelikheid en opvoeding, soos wat die Grieke gemeen het nie, maar ook nie deur die vervulling van die wet soos wat die Jode gemeen het nie. Mense is identies met hulle bose wil en kan daarom net deur God van hulle self bevry word. In geloof ontvang mense God se genade en in geloof word 'n radikale openheid vir God se toekoms aan hulle geskenk. Deur die genade van God word mense van hulle eie verlede bevry om ontvanklik te word vir God se genade wat altyd weer opnuut aan hulle geskenk word. God praat met ons deur Christus wat die einde van die geskiedenis is en deur sy Woord wat aan ons verkondig word. Deur die verkondiging van God se genade kom die enkeling voor God en moet die enkeling ' $n$ beslissing maak om hom- of haarself aan die genade van God oor te gee en so die outentiekheid van sy of haar eie bestaan te ontdek.

Tussen 1948 en 1953 verskyn Bultmann se Theologie des Neuen Testaments in drie aflewerings (Hammann [2009] 2012b:404-408). Hy bespreek die geloofstema grondig in die werk, maar fokus veral op Paulus en die Johannesevangelie se teologiese beskrywings van geloof. Wat Paulus betref, meen Bultmann ([1948-1953] 1961:315-331) dat hy teenoor die Joodse opvatting van sy tyd geglo het dat geloof, en nie werke nie, die voorwaarde is om geregtigheid van
God te ontvang. Hy het verder, in aansluiting by die sendingprediking van die Hellenistiese Christendom, geglo dat geloof die aanneming van die Christelike boodskap is.

Paulus verstaan geloof primêr as geloofsdaad, met ander woorde 'n daad van gehoorsaamheid teenoor God. Volgens Romeine 1:5 verstaan hy die essensie van sy apostelskap om 'die heidene tot geloofsgehoorsaamheid te bring.' Die gelowige aanneming van die evangelie is 'n daad van gehoorsaamheid teenoor God, omdat dit van ons vra om te bely dat die gekruisigde Jesus die Here is. Hierdie belydenis vereis dat ons ons eiewilligheid sal prysgee om voortaan gehoorsaam aan die Here te lewe. As gehoorsaamheidsdaad kan geloof nooit 'n menslike prestasie of menslike werk wees nie. In geloof onderwerp mense hulle gehoorsaam aan God om op die heilsweg te gaan wat Hy vir hulle bestem het en daarom neem gelowiges ook die kruis van Christus op. Geloof is gevolglik nie ' $n$ belewenis, ' $n$ godsdienstige of geestelike opvatting, of 'n sieletoestand nie. Dit kom ook nie in beweging deur die menslike wil wat deur berou of boetedoening aangevuur word nie. As gehoorsaamheid aan God is geloof wel altyd ' $n$ daad van beslissing.

Geloof word bely. Geloof word nie as menslike selfbeskrywing ter sprake gebring (verwoord) nie, maar as die belydenis van geloof. Die parallelle formulering van Romeine 10:9 dui dit mooi aan: 'As jy met jou mond bely dat Jesus die Here is en jy glo met jou hart dat God Hom uit die dood opgewek het, sal jy verlos word.' Geloof is daarom nie vroomheid of algemene vertroue op God nie. Geloof het 'dogmatiese' karakter in die sin dat dit die aanneming van 'n woord (die Evangeliewoord) is, dat dit geloof aan iets is wat aangedui kan word en dat dit op God se heilsdaad in Christus gerig is. Geloof sluit daarom noodwendig 'n element van kennis in. Mens eien jouself egter alleen geloofskennis toe in gehoorsaamheid aan God waardeur 'n nuwe selfverstaan ook aan jou ontsluit word. Geloof en kennis is as nuwe selfverstaan identies. Geloof het egter nie 'dogmatiese' karakter in die sin dat die verkondigde Woord ' $n$ referaat oor die historiese verlede is nie. Dit is nie 'n leer oor objektiewe sake (feite) nie, maar die verkondigde Woord word as eksistensieel relevant en as waar aanvaar. Die Woord is kerugma, aanspraak, oproep en belofte. Dit is self ' $n$ goddelike genadedaad wat aan ons geskenk word. Daarom is die aanneming van die Woord in geloof altyd gehoorsaamheid, waardering en belydenis.

Geloof sluit 'n element van hoop in. Geloof is nie 'n na-binnegerigtheid van die mens nie, maar as gerigtheid op God is dit ook gerigtheid op die toekoms. Geregtigheid as die doel waarna geloof strewe, is nie 'n inherente kwaliteit van mense nie, maar word aan hulle geskenk binne hulle verhouding met God. Waar geregtigheid 'n teenwoordige moontlikheid geword het, is die teenwoordigheid daarvan nie 'n tydelike en dus verganklike moontlikheid nie. Geregtigheid word as eskatologiese moontlikheid teenwoordig en is daarom altyd ook as toekomstige werklikheid vóór die gelowiges wat reeds geregtigheid van God ontvang het. Om te hoop, beteken om vry en oop vir die toekoms te wees en om die 
sorge van die lewe en jou besorgdheid daaroor gehoorsaam aan God toe te vertrou. Die sonde (van ongehoorsaamheid) is niks anders as om uit eie vermoëns te probeer lewe in die waan dat jy self jou eie toekoms kan bepaal en gevolglik daarvoor verantwoordelikheid wil neem nie. Wie sy of haar eie toekoms probeer bepaal, lewe voortdurend in angs, maar hulle wat in geloof die sorge van die lewe in God se hande lê, word bevry van angs. Omdat geloof hoop is, laat geloof mense geduldig op God se hulp wag.

Hoewel geloof mense uit angs bevry, korrespondeer dit op 'n eiesoortige wyse met vrees (ontsag), wat 'n onontbeerlike konstitutiewe element van geloof is en wat dit op die genade van God gerig hou. Vrees is niks anders nie as 'n besef van jou eie nietigheid en jou deurlopende aangewesenheid op God se genade. Uit Romeine 11:20 is dit duidelik dat geloofsvrees mens nie alleen bevry van 'n valse selfversekerdheid nie, maar jou ook aan jou verantwoordelikheid herinner om nie langer onder die wet te staan nie en om uit die genade van God te leef. Geloof is altyd aan bedreigings en versoekings uitgelewer, daarom is egte geloof nooit valse geloofsekerheid nie, maar ' $n$ besef van jou afhanklikheid van God. Geloof is nooit 'n heen en weer gerondvallery tussen hoop en vrees nie, want hoop en vrees is korrelate en om te glo, beteken om jou nie op eie kragte en vermoëns te verlaat nie, maar op die genade van God. Geloof is 'n beweging tussen die 'nie meer nie' en die 'nog nie'. Gelowiges is nie meer slawe van hulleself en hulle eie verlede nie, maar wag op God se genade wat hulle altyd weer opnuut toeval.

Geloof is natuurlik ook vertroue. As gehoorsaamheid aan God, is geloof vanselfsprekend ook vertroue op God. Radikale vertroue op God is niks anders nie as om jou eie besorgdheid en mag prys te gee en gehoorsaam jou sorge voor die voete van God te lê nie. Geloof is daarom nie algemene vertroue op God nie, maar vertroue wat spesifiek in God se heilsdaad (die kruis van Christus) gewortel is. Geloof beteken daarom ook om in vertroue op God jou kruis op te neem.

Geloof is die aanneming van die verkondiging (kerugma), maar dan nie net as blote kennisname daarvan en toestemming daartoe nie. Geloof as aanneming van die verkondiging vra gehoorsaamheid aan God wat 'n nuwe selfverstaan insluit. Geloof is nooit ' $n$ daad wat in die verlede vasgevang is nie en dit is ook nie 'n kwaliteit van die mens nie, maar is die werkkrag wat deur God geskenk word wat die gang van die konkrete lewe bepaal. Geloof word daarom gekonkretiseer in die lewensverloop binne spesifieke verhoudings wat gestalte kry. 'n Gelowige lewe is in konstante beweging.

'n Geloofslewe kry gestalte in individuele genadegawes wat die gelowiges van God ontvang. Wie in geloof lewe, bly in Christus en lewe met ander woorde vanuit die goddelike heilsdaad. As antwoord op die verkondigde Woord, is geloof heilsgebeure en gevolglik eskatologiese gebeure. God se nuut-aangekondigde heilsweg kan alleen in geloof betree word.
Wat Johannes betref, meen Bultmann ([1948-1953] 1961:422-445) dat sy Evangelie geskryf is 'sodat julle kan glo dat Jesus die Christus is, die Seun van God, en dat julle deur te glo die lewe in sy Naam kan hê' (Joh 20:31). Johannes vind by die gemeenskaplik Christelike oortuiging aansluiting dat geloof die aanname van die Christelike boodskap is. Omdat Christus en sy Woord vir Johannes identies is, kan sy Woord ook die onderwerp van geloof wees. In die verkondigde Woord word Christus as die primêre verkondiger ontmoet. Omdat Woord en persoon identies is, ontstaan geloof deur die hoor van die Woord (Joh 5:24). Hoor beteken hier nie slegs om kennis te neem nie, maar om deur die Woord te leer ken en te ontmoet.

Net soos wat Christus se persoon en Woord identies is, kan sy persoon en werk ook as identies gereken word. Mens kan, net soos wat jy Christus deur sy Woord hoor, Hom ook deur sy werk sien (Joh 5:36, 6:40 en 12:45). Sien is die waarneming deur geloof dat waarheid en lewe alleen deur die persoon Jesus bemiddel word en dit alleen deur Hom gevind kan word. Dit is nie net die eerste gelowiges wat Jesus en sy werk kon sien nie. Gelowiges kan ten alle tye Jesus sien, want Jesus, die openbaarder van God se wil, was nie net die vleesgeworde Seun van God vir sy eie tydgenote nie. Hy bly dit vir altyd. Die rol van die eerste gelowiges is daarom nie dat hulle as ooggetuies die sekerheid van die latere gelowiges se geloof waarborg nie, maar dat hulle die eerstes was om die aanstoot te bowe te kom dat die Woord vlees geword het.

Johannes tref nie 'n onderskeid tussen geloof in God en vertroue op Hom nie. Die een kan eenvoudig nie sonder die ander een nie. Trouens, geloof en vertroue val geheel en al saam.

Net soos wat Jesus deur die gelowiges gehoor of gesien word, word Hy ook deur hulle geken. Die beskrywings hoor, sien en ken, word uitruilbaar deur Johannes gebruik, maar word ook aanvullend tot mekaar gebruik. Net soos wat gelowiges in Jesus glo, ken hulle Hom ook. Trouens, glo en ken moet nie as twee verskillende dade verstaan word nie, maar as een en dieselfde daad wat op twee verskillende maniere beskryf word. Geloof is nie die aanneming van 'n dogma wat esoteriese kennis ontsluit of 'n mistiese aanskoue moontlik maak nie, maar dit is alles! Christus kan alleen in geloof geken word. Kennis is 'n struktuurmoment van geloof.

Bultmann ([1948-1953] 1961:427-445) bring agt perspektiewe ter sprake wanneer hy geloof as eskatologiese bestaan volgens Johannes bespreek.

- Wanneer die wêreld Jesus nie glo nie, maak die wêreld nie net ' $n$ fout nie, maar word die wêreld self leuenagtig. Die oproep van die evangelie tot geloof is daarom altyd ook 'n oproep om afstand te doen van die wêreld en van wêreldlike maatstawwe, waardes en oordele, van skynsekerhede en lewensleuens en om daarom ook mens se vorige wêreldlike selfverstaan prys te gee.

- Elke geloofsbeslissing is self ook 'n geskenk van God. Die dissipels het Jesus nie gekies nie, maar Hy het hulle gekies 
(Joh 15:16). Hierin vind geloof sekerheid. Die sekerheid van die geloof is dus tegelyk subjektief en objektief, want geloof vind nie sekerheid in die geloof self nie, maar in Hom in wie geglo word.

- As oorwinning van die aanstoot van die evangelie en keuse teen die wêreld ontsluit geloof die eskatologiese bestaan. Die gelowiges word in die wêreld deur die geloof van ' $n$ wêreldlike bestaan ontneem. Vir gelowiges is God se gerig reeds agter die rug en het hulle reeds van die dood na die lewe oorgegaan. Gelowiges besef dat hulle altyd van die genade van God afhanklik is, maar net so besef hulle dat hulle verhouding tot God deur Christus bepaal word en hulle daarom altyd getroos kan lewe. Deur Christus word ons oortuig van God se liefde.

- Wie God se liefde ontvang, word verplig om ook in liefde te lewe. Geloof en liefde vorm 'n onlosmaaklike eenheid. In geloof word alle dade wat gelowiges doen dade van liefde. Die eskatologiese lewens van die gelowiges kry beslag as lewens in liefde.

- As afskeidsgeskenk gee Jesus die vrede van die eindtyd aan die gelowiges (Joh 14:27). Die vrede en heil wat Jesus skenk, kan nie as toestand verwerklik word nie, maar wel as gebeure, naamlik as geloofsdaad. In die geloof verstaan ons onsself nie meer in terme van die wêreld nie, maar in terme van die heil wat ons van God ontvang het en so lewe ons in die vrede wat God aan ons skenk.

- Om in geloof te lewe, beteken om in Christus of in verbondenheid metHom telewe. Dieeenheid metChristus is tegelyk ook eenheid met die Vader. Geloof in Jesus is algehele vertroue op Hom, want soos wat die beeld van die wynstok en die lote aandui, is die verhouding tussen Jesus en die gelowiges altyd 'n ongelyke verhouding waarin Jesus heil skenk en die gelowiges totaal en al van Jesus afhanklik is vir verlossing.

- 'n Lewe in geloof is 'n lewe in die Gees. Kennis van God sowel as die verkondiging van die Woord, hang van die kragtige werking van die Gees af. Wanneer die Gees die Gees van die waarheid genoem word wat ons in alles onderrig (Joh 14:26) en ons in die volle waarheid lei (Joh 16:13), wil Johannes nie die indruk skep dat Jesus se verkondiging kwantitatief onvolledig is nie, maar dat dit in wese onafgeslote is. Jesus se boodskap kry voortdurend gestalte in nuwe verkondigingsdade wat deur die krag van die Gees geskied.

- Hoewel Johannes geen belangstelling toon in die Christelike kultus of die organisasie van die kerk nie, verstaan hy die gelowiges nie as blote individue nie, maar as 'n gemeenskap wat saamkom en hulle van die wêreld onderskei.

Een van die voorlesings wat Bultmann op besoek aan die Verenigde State van Amerika (VSA) gedurende 1951 gelewer het, verdien ook aandag. Jesus Christus und die Mythologie is later ook gepubliseer - in 1958 in Engels en in 1964 in Duits (Bultmann [1958-1964] 1975b:141-189). In hierdie voorlesing verdedig Bultmann hom teen die beskuldiging dat sy ontmitologiseringsprogram die rasionalisering van die Christelike boodskap sou behels. Deur ontmitologisering wil hy wel die Christelike boodskap bevry van die oënskynlike aanstoot van 'n verouderde wêreldbeeld om hulle met die werklike aanstoot van die evangelie te konfronteer, naamlik die woord van die kruis. Ontmitologisering maak duidelik dat die Woord van God mense van hulle angs en die strewe na selfverwerfde sekerheid bevry om aan hulle ware vryheid te skenk - dit is vryheid van die wêreld en vryheid vir die toekoms van God. Die boodskap van God as die handelende God moet ge-ontmitologiseer word, sodat God se handeling nie langer voorgestel word as mirakelagtige optrede wat die kousaliteit van natuurlike gebeure deurbreek nie. Ons kan eenvoudig nie objektief oor God en sy werk praat nie, maar net in terme van wat Hy aan ons doen en wat Hy met ons doen (Bultmann [1958-1964] 1975b:181; Schmithals 1967:115).

In die artikel Zum Problem der Entmythologisierung wat in 1952 in Kerugma und Mythos II verskyn skryf Bultmann dat radikale ontmitologisering ' $n$ parallel is vir die PauliniesLutherse leer oor die regverdiging sonder wetsonderhouding en alleen deur geloof. Soos die regverdigingsleer slaan dit elke moontlike valse sekerheid en elke valse verlange na sekerheid die nek in - hetsy of die sekerheid op goeie werke of op aanwysbare kennis gebou word (Bultmann 1952:207).

In die Gifford Lectures wat Bultmann gedurende 1955 in Edinburgh aanbied en wat later ([1954-1955] [1962] 1975a) onder die titel History and Eschatology gepubliseer word, redeneer Bultmann dat mense vanuit die perspektief van die Christelike geloof, nie oor die vryheid beskik om die verantwoordelikheid wat die geskiedenis op hulle plaas, te ontsnap nie. Mense word in so 'n mate deur die geskiedenis bepaal dat hulle van hulle eintlike self vervreemd bly. Mense kan alleen die vryheid waarna hulle smag deur die verkondiging van God se genade as 'n geskenk van God ontvang. Waar God se evangelie gehoor en geglo word, gebeur dit dat die teenwoordigheid 'n eskatologiese oomblik word (Bultmann [1954-1955] [1962] 1975a:184). Bultmann se bekende uitspraak dat Jesus in die kerugma opgestaan het, beteken dat dit Jesus se Woord is wat die hoorder in die kerugma hoor. Opstandingsgeloof beteken om aan die Christus te glo wat in die kerugma teenwoordig is.

In sy laaste openbare voordrag wat Bultmann in 1963 by die Universiteit van Marburg gelewer het, pleit hy daarvoor dat die Christelike geloof van oorwoekering (Überfremdung) deur godsdienstigheid bevry moet word. Hy handel oor die afwesigheid van God in die moderne Amerikaanse kultuur en huldig die standpunt dat mense deur hulle godsdienstigheid aan hulleself die plek toeken wat die Christelike openbaringsgeloof toekom. Dit het tot gevolg dat die transendensie van God verlore gaan in moderne sekularisasie en dat ons ons gevolglik reeds in 'n na-Christelike tydvak bevind. Hierdie situasie beteken egter nie dat dit onmoontlik vir mense geword het om God hier en nou as die transendente God te ontmoet nie. In hierdie verband het die verkondiging van die evangelie vandag steeds 'n funksie (Hammann [2009] 2012b:448). 
Bultmann se twee eksegetiese bydraes oor die Johannes briewe en 2 Korintiërs (Bultmann 1969, 1976) lewer nie enige nuwe perspektiewe op ten opsigte van sy verstaan van geloof nie (Hammann [2009] 2012b:461-462). Weereens beklemtoon hy dat versoening tussen God en mense alleen moontlik gemaak word deur die verkondiging wat in geloof aangeneem word. Verkondiging is daarom deel van die eskatologiese gebeure (Hammann [2009] 2012b:462).

Bultmann het in sy lewe nie net 'n bepaalde teologiese standpunt verdedig oor wat geloof is nie, maar het sy geloofsoortuiging ook konsekwent uitgeleef. Sy geloofsoortuiging kom byvoorbeeld duidelik aan die lig in sy reaksie op die toekenning van die Pruisiese orde van meriete aan hom op vier en tagtig-jarige ouderdom. Hoewel Bultmann groot waarde aan hierdie toekenning geheg het, het hy in sy privaat hoedanigheid daarop gewys dat mens in geloof alle werke, prestasies en verdienstes wat tot selfverheerliking kan lei, moet prysgee en jouself vertrouend op God aan die genade van God moet uitlewer (Hammann [2009] 2012b:481).

\section{Beoordeling}

Die etikettering van Bultmann as ongelowige neem gewoonlik as vertrekpunt dat hy nie die volledige ortodokse kanon van 'heilsfeite' onderskrywe nie, maar neem dan nie in ag dat soos wat Bultmann aandui - geloof nie die onderskrywing van sekere heilsfeite of instemming tot die regte leer van die kerk is nie, maar wel vertroue op God se heilsdade wat deur die Woord verkondig word. Geloof is ook nie naïewe goedgelowigheid met die gevolglike opheffing van menslike redelikheid nie. Bedenkinge teen Bultmann vanuit hierdie hoek berus op onwilligheid om sy werk te lees en saam met hom die saak te bedink wat ter sprake is (Jüngel 1990:68).

Mens sou wel voorbehoude kon hê oor Bultmann se standpunt dat die vraag na die waarheid alleen in terme van die historiese oomblik wanneer die mens met die verkondiging gekonfronteer word ter sprake kom en nie ook in terme van die indikatiewe vertelling van die geskiedenis nie. Laasgenoemde hoef nie die objektivering van God te behels nie (Jüngel 1990:69-71). Dit bly egter 'n uitdagende opgawe vir die teologie om aan God as 'Gegen-Über' te dink, sonder om van Hom 'n 'Gegen-Stand' te maak (Von Sass 2011:268). Bultmann gee nie genoegsame aandag daaraan dat die momentele aard van die geloofsbeslissing in spanning staan met geloof as voortdurende vertroue en gehoorsaamheid aan God se wil nie (Hammann [2009] 2012b:233; Von Sass 2011:263). Laastens, word die mens werklik deur die menslike daad gekonstitueer (inaggenome Bultmann se onderskeid tussen daad en werk), of dalk eerder deur die Woord van God (Ebeling [1966-1967] 1969b:343-371)?

\section{Erkenning \\ Mededingende belange}

Die outeur verklaar dat hy geen finansiële of persoonlike verhouding(s) het wat hom op 'n voordelige of nadelige wyse in die skryf van die artikel beïnvloed het nie.

\section{Literatuurverwysings}

Bultmann, R., 1913, 'Theologische Wissenschafte und kirchliche Praxis', Oldenburgisches Kirchenblatt 19, 123-127; 133-135.

Bultmann, R., 1925, 'Der christliche Sinn von Glaube, Liebe, Hoffnung: Skizze eines Vortrages', Zeitschrift für den evangelischen Religionsunterricht 36, 170-172.

Bultmann, R., [1930] 1927-1931, s.v. 'Paulus' in H. Gunkel \& L. Zscharnack (Hrsg.), Die Religion Geschichte und Gegenwart, Handwörterbuch für Theologie und Religionswissenschaft, 2. Aufl., J.C.B. Mohr (Paul Siebeck), Tübingen, 4. Bd. pp. 1019-1045.

Bultmann, R., 1952, 'Zum Problem der Entmythologisierung', in H-W. Bartsch (Hrsg.), Kerygma und Mythos II, S. 177-208, Herbert Reich, Hamburg.

Bultmann, R., [1948-1953] 1961, Theologie des Neuen Testaments, 4. Aufl., J.C.B. Mohr (Paul Siebeck), Tübingen.

Bultmann, R., [1948] 1968a, 'Humanismus und Christentum', in Glauben und Verstehen, Gesammelte Aufsätze, 2. Bd., 5. Aufl., pp. 133-148, J.C.B. Mohr (Paul Siebeck), Tübingen.

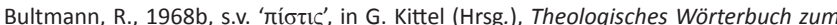
Neuen Testament, W. Kohlhammer Verlag, Stuttgart, 6. Bd., pp. 174-228.

Bultmann, R., 1969, Die drei Johannesbriefe, 2. Aufl., Vandenhoeck \& Ruprecht, Göttingen.

Bultmann, R., [1954-1955] [1962] 1975a, History and eschatology, 3rd edn., Edinburgh University Press, Edinburgh. (The Gifford Lectures).

Bultmann, R., [1958-1964] 1975b, 'Jesus Christus und die Mythologie', in Glauben und Verstehen: Gesammelte Aufsätze, 4. Bd., 3. Aufl., pp. 141-189, J.C.B. Mohr (Paul Siebeck), Tübingen.

Bultmann, R., 1976, Der zweite Brief an die Korinther, Vandenhoeck \& Ruprecht, Göttingen.

Bultmann, R., [1926] 1977a, Jesus, 3. Aufl., Gütersloher Verlagshaus Mohn, Gütersloh.

Bultmann, R., [1922] 1977b, 'Karl Barths "Römerbrief" in 2. Auflage', in J. Moltmann (Hrsg.) Anfänge der dialektischen Theologie, Teil I, 4. Aufl., pp. 119-142, Kaiser Verlag, München.

Bultmann. R., 1978, Das Evangelium des Johannes, 20. Aufl., Vandenhoeck \& Ruprecht, Göttingen.

Bultmann, R., [1931] 1979, Die Geschichte der synoptischen tradition, 5. Aufl., Vandenhoeck \& Ruprecht, Göttingen.

Bultmann, R., [1929] 1980a, 'Kirche und Lehre im Neuen Testament', in Glauben und Verstehen: Gesammelte Aufsätze, 1, Bd., 8. Aufl., pp. 153-187, J.C.B. Mohr (Paul Siebeck), Tübingen

Bultmann, R., [1924] 1980b, 'Die liberale Theologie und die jüngste theologische Bewegung', in Glauben und Verstehen: Gesammelte Aufsätze, 1. Bd., 8. Aufl., pp. 1-25, J.C.B. Mohr (Paul Siebeck), Tübingen.

Bultmann, R., [1927] 1980c, 'Zur Frage der Christologie', in Glauben und Verstehen Gesammelte Aufsätze, 1. Bd., 8. Aufl., pp. 85-113, J.C.B. Mohr (Paul Siebeck), Tübingen.

Bultmann, R., 1984, Theologische Enzyklopädie, E. Jüngel \& K.W. Müller (Hrsg.), J.C.B. Mohr (Paul Siebeck), Tübingen.

Bultmann, R., [1941] 1998, Neues Testament und Mythologie. Das Problem der Entmythologisierung der neutestamentlichen Verkündigung, E. Jüngel (Hrsg.), Nachdruck der 1941 erschienenen Fassung, Kaiser Verlag, München. (Beiträge zur evangelischen Theologie, 96).

Bultmann, R., [1949] 2000, Das Urchristentum im Rahmen der antiken Religionen, Patmos, Düsseldorf.

Bultmann, R., [1926] 2002a, 'Die evangelisch-theologische Wissenschaft in der Gegenwart', in M. Dreher \& K.W. Müller (Hrsg.), Theologie als Kritik, Ausgewählte Rezensionen und Forschungsberichte, pp. 156-166, J.C.B. Mohr (Paul Siebeck), Rezensionen
Tübingen.

Bultmann, R., [1925] 2002b, 'Das Problem einer theologischen Exegese des Neuen Testaments', in A. Lindemann (Hrsg.), Neues Testament und christliche Existenz: Theologische Aufsätze, pp. 249-277, J.C.B. Mohr (Paul Siebeck), Tübingen.

Ebeling, G., [1967] 1969a, 'Gewissheit und Zweifel, Die Situation des Glaubens im Zeitalter nach Luther und Descartes', 2. Bd., Wort und Glaube: Beiträge zur Fundamentaltheologie und zur Lehre von Gott, J.C.B. Mohr (Paul Siebeck), Tübingen.

Ebeling, G., [1966-1967] 1969b, 'Zum Verständnis von R. Bultmanns Aufsatz: "Welchen Sinn hat es, von Gott zu reden?"', 2. Bd., Wort und Glaube: Beiträge zur Fundamentaltheologie und zur Lehre von Gott, J.C.B. Mohr (Paul Siebeck), Tübingen.

Ebeling, G., 1979, Dogmatik des christlichen Glaubens, 1. Bd., J.C.B. Mohr (Paul Siebeck), Tübingen

Hammann, K., 2012a, 'Der Glaube als freie Tat des Gehorsams Herkunft, Bedeutung und Problematik einer Denkfigur Rudolf Bultmanns', Zeitschrift für Theologie und Kirche 109(2), 206-234. http://dx.doi.org/10.1628/004435412800650891

Hammann, K., [2009] 2012b, Rudolf Bultmann. Eine Biographie, 3. Aufl., J.C.B. Mohr (Paul Siebeck), Tübingen.

Hauschildt, E., 1989. 'Rudolf Bultmanns Predigten. Existentiale Interpretation und lutherische Erbe: mit einem neuen Verzeichnis der Veröffentlichungen Bultmanns', Evangelische Verlagsanstalt, Marburg.

Heidegger, M., [1927] 1978, 'Phänomenologie und Theologie', in Wegmarken, 2. Aufl., pp. 45-78, Vittorio Klostermann, Frankfurt am Main.

Heidegger, M., [1927] 2001, Sein und Zeit, 18. Aufl., Max Niemeyer, Tübingen. 
Jüngel, E., 1990, 'Glauben und Verstehen. Zum Theologiebegriff Rudolf Bultmanns', in Wertlose Wahrheit: Zur Identität und Relevanz des christlichen Glaubens: in Wertlose Wahrheit: Zur Identität und Relevanz des christlichen
Theologische Erörterungen III, pp. 16-77, Kaiser Verlag, München.

Pannenberg, W., 1993, Systematische Theologie, 3. Bd., Vandenhoeck \& Ruprecht, Göttingen.
Schmithals, W., 1967, Die Theologie Rudolf Bultmanns, J.C.B. Mohr (Paul Siebeck), Tübingen.

Von Sass, H., 2011, 'assensus fiduciae, Glaube als Vertrauen bei Rudolf Bultmann', Kerygma und Dogma 57, 243-268. http://dx.doi.org/10.13109/ kedo.2011.57.3.243 